\title{
Current concepts of polymicrogyria
}

\author{
A. James Barkovich
}

Received: 13 November 2009 / Accepted: 1 December 2009/Published online: 3 March 2010

(C) The Author(s) 2009. This article is published with open access at Springerlink.com

\begin{abstract}
Polymicrogyria is one of the most common malformations of cortical development. It has been known for many years and its clinical and MRI manifestations are well described. Recent advances in imaging, however, have revealed that polymicrogyria has many different appearances on MR imaging, suggesting that is may be a more heterogeneous malformation than previously suspected. The clinical and imaging heterogeneity of polymicrogyria is explored in this review.
\end{abstract}

Keywords Polymicrogyria $\cdot$ Epilepsy $\cdot$ Malformations of cortical development $\cdot$ Magnetic resonance imaging

\section{Introduction}

Polymicrogyria is a malformation of cortical development in which the process of normal cerebral cortical development is disturbed late in the stage of neuronal migration or early in the stage of cortical organization; thus, it is considered a disorder of neuronal organization [1]. As a result of these disturbances to the developmental process, the deeper layers of the cerebral cortex develop abnormally and multiple small gyri form within the cortex [2]. Polymicrogyria has a range of histologic appearances, all having in common a derangement of the normal six-layered lamination of the cortex, an associated derangement of sulcation, and fusion of the molecular layer across sulci [3-5]. In areas of polymicrogyria, no normal sulci are seen. Causes of polymicrogyria

\footnotetext{
A. J. Barkovich $(\bowtie)$

Neuroradiology, Room L371,

University of California at San Francisco,

505 Parnassus Avenue,

San Francisco, CA 94143-0628, USA

e-mail: Jim.Barkovich@radiology.ucsf.edu
}

include congenital infection (particularly cytomegalovirus infection $[6,7])$, localized or diffuse in utero ischemia $[8,9]$, or mutations (Table 1) [10-23].

Patients with polymicrogyria may have a wide variety of clinical presentations, ranging from hemiparesis or partial epilepsy to developmental delay, quadriparesis, and medically refractory, intractable epilepsy; the neurologic disability appears to depend upon the portion[s] of brain involved, but may also depend upon the type of polymicrogyria and the presence or absence of associated anomalies. Neurologic manifestations are similar among patients who have polymicrogyria due to different causes $[6,22,24,25]$. The severity of the clinical presentation and age at presentation depend mostly upon the extent of cortical involvement; bilateral involvement and involvement of more than half of a single hemisphere are poor prognostic indicators, portending moderate to severe developmental delay and significant motor dysfunction [25].

Polymicrogyria affects variable portions of the cerebral cortex: it may be focal, multifocal, or diffuse; it may be unilateral, bilateral, and asymmetrical; or bilateral and symmetrical. The most common location (in $60-70 \%$ of cases [26]) is around the sylvian fissure, particularly the posterior aspect of the fissure; however, any part of the cerebral cortex, including the frontal, occipital, and temporal lobes, can be affected [3, 24-28]. Polymicrogyria may be an isolated malformation or it may be associated with other brain malformations; when other malformations are identified, the most common are corpus callosum agenesis and hypogenesis, cerebellar hypoplasia [29], periventricular nodular heterotopia [30], and subcortical heterotopia [31]. Affected patients may be microcephalic, normocephalic, or macrocephalic [22].

Several specific syndromes are associated with cerebral polymicrogyria (Table 2). Some of the best known of these 
Table 1 Genes associated with polymicrogyria.

are Aicardi syndrome (OMIM 304050 [32, 33]), Delleman syndrome (oculo-cerebral-cutaneous syndrome, OMIM 164180 [34, 35]), DiGeorge syndrome (OMIM 188400, also called the 22q11.2 deletion syndrome in which several genes are deleted [19]), Warburg Micro syndrome (OMIM

Table 2 Multiple congenital anomaly syndromes with polymicrogyria.

\begin{tabular}{|c|c|c|}
\hline Syndrome & Anomalies & Gene \\
\hline Aicardi syndrome & $\begin{array}{l}\text { Callosal agenesis } \\
\text { Polymicrogyria } \\
\text { Heterotopia [periventricular and } \\
\text { subcortical] } \\
\text { Retinal anomalies }\end{array}$ & $\begin{array}{l}\text { Not } \\
\text { known }\end{array}$ \\
\hline Delleman syndrome & $\begin{array}{l}\text { Callosal agenesis } \\
\text { Cystic microphthalmia } \\
\text { Frontal polymicrogyria } \\
\text { Periventricular heterotopia } \\
\text { Large, dysplastic tectum } \\
\text { Absent } \mathrm{Cb} \text { vermis }\end{array}$ & $\begin{array}{l}\text { Not } \\
\text { known }\end{array}$ \\
\hline DiGeorge syndrome & $\begin{array}{l}\text { Parathyroid hypoplasia } \\
\text { Thymic hypoplasia } \\
\text { Cleft palate } \\
\text { Cardiac malformations } \\
\text { Facial anomalies } \\
\text { Polymicrogyria [perisylvian, right } \\
\text { hemisphere preferred] }\end{array}$ & $22 \mathrm{q} 11.2$ \\
\hline $\begin{array}{l}\text { Warburg Micro } \\
\text { syndrome }\end{array}$ & $\begin{array}{l}\text { Microcephaly } \\
\text { Microcornea } \\
\text { Congenital cataract } \\
\text { Optic atrophy } \\
\text { Hypogenitalism with hypotonia } \\
\text { Callosal hypo- or agenesis } \\
\text { Frontoparietal polymicrogyria }\end{array}$ & $2 \mathrm{q} 21.3$ \\
\hline $\begin{array}{l}\text { D-bifunctional } \\
\text { protein deficiency }\end{array}$ & $\begin{array}{l}\text { Generalized osteopenia } \\
\text { Bilateral perisylvian polymicrogyria } \\
\text { Large anterior fontanelle } \\
\text { Frontal bossing } \\
\text { Up-slanting palpebral fissures } \\
\text { Hypertelorism }\end{array}$ & $5 q 2$ \\
\hline
\end{tabular}

600118 [36-38]), and D-bifunctional protein deficiency (OMIM 261515) [39]. Many others will likely be found.

The imaging appearance of polymicrogyria is variable. This variability is most likely a result of three factors: imaging factors (amount of gray matter-white matter contrast, thickness of the slices); the stage of maturity/ myelination of the brain at the time of the imaging study; and, in all likelihood, the type of PMG. In a previous analysis of PMG, I noted that it can have a coarse appearance or a delicate appearance and that the appearance seen in the so-called cobblestone malformations differs from that seen in most bilateral polymicrogyria syndromes [40]. The precise reasons for these differing appearances are not known, but the development of the cerebral cortex is so complex that it is not surprising that disruptions of the processes of late cortical migration and cortical organization at
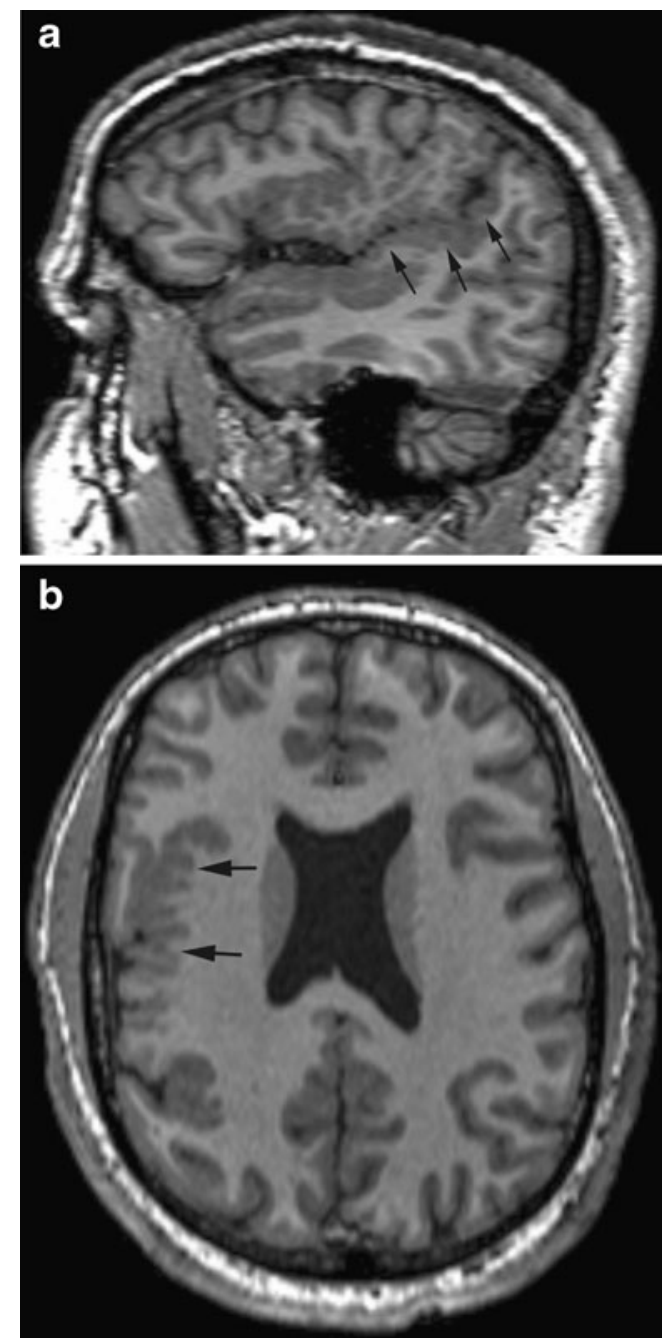

Fig. 1 Parasagittal (a) and axial (b) T1-weighted images show the delicate appearance of PMG (black arrows) in the right sylvian and suprasylvian cortex. Note the continuity of the posterior sylvian fissure on the parasagittal image (a); this is diagnostic of perisylvian PMG 
different stages might result in slightly different malformations. The cortical surface can have multiple small, delicate gyri (Fig. 1) or appear thick and irregularly bumpy (Fig. 2) or be paradoxically smooth (Fig. 3) because the outer cortical (molecular) layer fuses over the microsulci. Sometimes the cortex appears thick and coarse (with an appearance of "palisades" of cortex [40], (Fig. 4)), while other times the microgyri appear fine and delicate (Fig. 1), even when the brains are similarly myelinated. However, these variations in appearance may not be detectable on routine, $5-\mathrm{mm}$ thick images. Therefore, images with thin sections and optimal gray matter-white matter contrast [we acquire volume 3DFT spoiled gradient acquisition (T1 weighted) and volume 3DFT fast spin echo (T2 weighted) images, both in the sagittal plane with $\leq 1.5 \mathrm{~mm}$ partition size] should always be
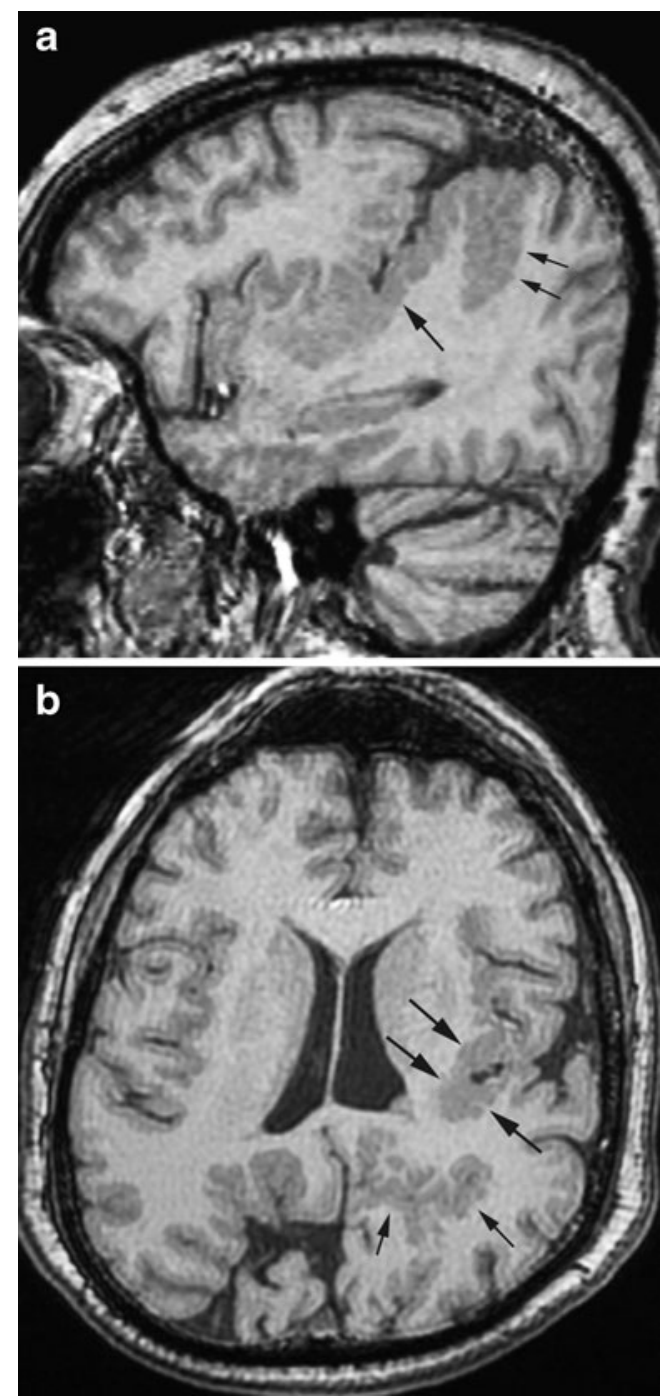

Fig. 2 Thick and irregularly bumpy, "coarse" appearance of PMG. Parasagittal (a) and axial (b) images show coarse PMG in the parietooccipital (small black arrows) and perisylvian (large black arrows) regions

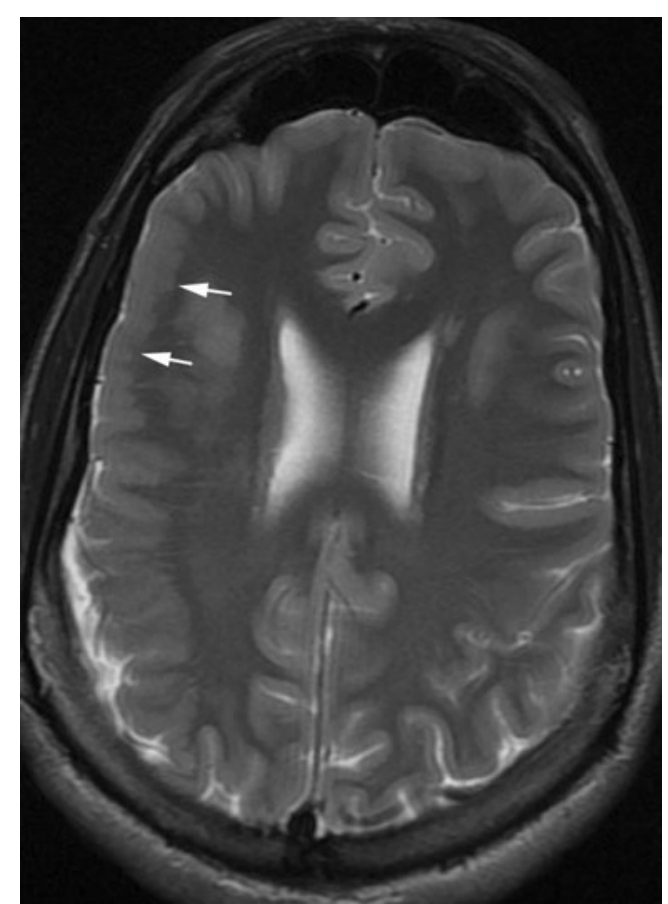

Fig. 3 Axial FSE T2 weighted image shows right frontal PMG (white arrows) with fusion of the molecular layer of cortex resulting in paradoxically smooth cortical surface

acquired. Evaluation in three planes is often necessary to detect irregularities of the gray matter-white matter junction, which are often the most convincing evidence of dysplastic brain (Fig. 3) [41]; this is most easily accomplished via volumetric acquisition with display in all three orthogonal

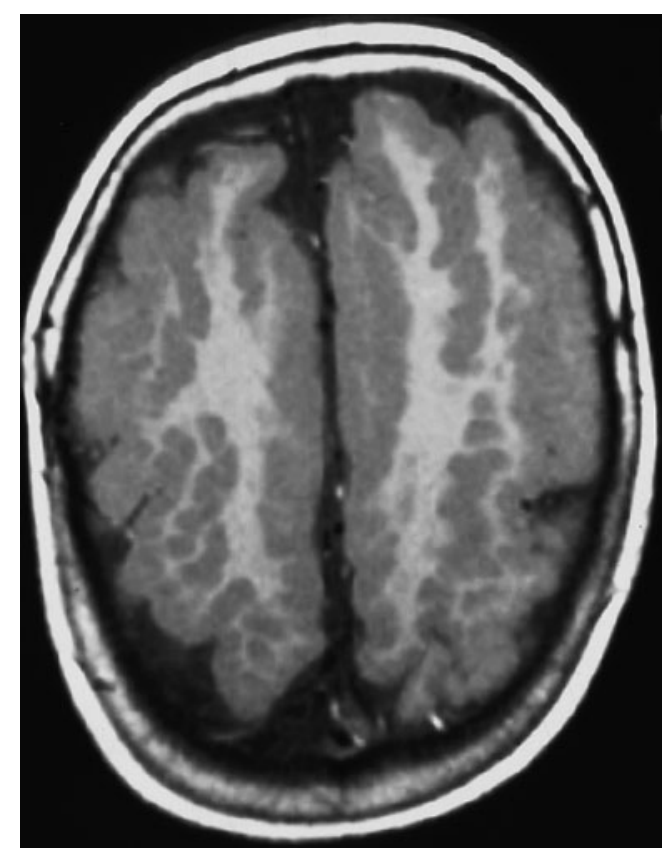

Fig. 4 Axial T1-weighted image shows diffuse coarse PMG with an appearance of "palisades" of cortex 
planes (sagittal, axial, and coronal). The volume acquisitions can be displayed as three-dimensional surface images (Fig. 5) and can be utilized for stereotactic localization, aiding in surgical therapy, if appropriate. The degree of myelination affects the appearance. In unmyelinated regions, the inner surface of the polymicrogyric cortex looks thin [2-3 mm] and bumpy, while in myelinated areas it looks thicker $(5-8 \mathrm{~mm})$ and relatively smooth [42]. The reason proposed for this is that a 4$5 \mathrm{~mm}$ layer of gliotic white matter runs through the polymicrogyric cortex, blending in with white matter in the unmyelinated brain and blending in with cortex after myelination [42]. Finally, as stated earlier, polymicrogyria is almost certainly a heterogeneous malformation that can have many different appearances: thick and coarse, fine and delicate, with shallow or deep sulci. Whatever the reason, it is important to realize that a spectrum of cortical appearances, all having some sort of small gyri, can be seen in patients with polymicrogyria.

In addition to the variability of the appearance of polymicrogyria, the location of polymicrogyria is extremely variable. It may be superficial, with the cortex appearing
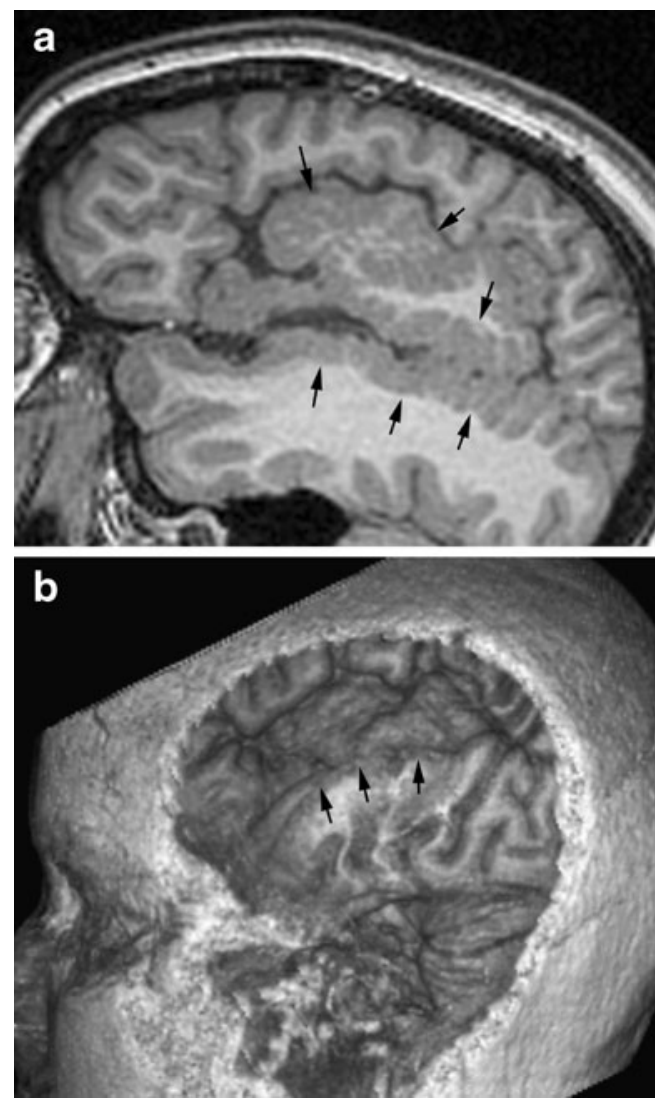

Fig. 5 Surface rendering of PMG from volumetric acquisition of data. a Image shows a parasagittal image of extensive perisylvian coarse PMG (arrows). The surface rendering (b) shows the absence of normal sulci and the bumpy cortical surface in the affected area (arrows) flat and congruent to the arc of normal cortex, or may course radially inward, as if it were buckled or folded toward the ventricle. This infolding of cortex may be small or large, but close examination will show that the cortical features are similar [bumpy, irregular inner and outer cortical surfaces] in both the superficial and radially folded types. Polymicrogyria may be unilateral $(\sim 40 \%)$ or bilateral $(\sim 60 \%)$. The cortex surrounding the sylvian fissures is involved in $\sim 80 \%$ of cases, with the frontal lobe being most commonly involved $(\sim 70 \%)$, followed by parietal $(63 \%)$, temporal (38\%), and occipital (7\%) lobes [28]. The striate cortex, cingulate gyrus, hippocampus, and gyrus rectus are typically spared [28]. Polymicrogyria is sometimes calcified, but it is difficult to know the frequency because few patients are studied with CT. It is not clear if the calcification is of any significance. Finally, it is important
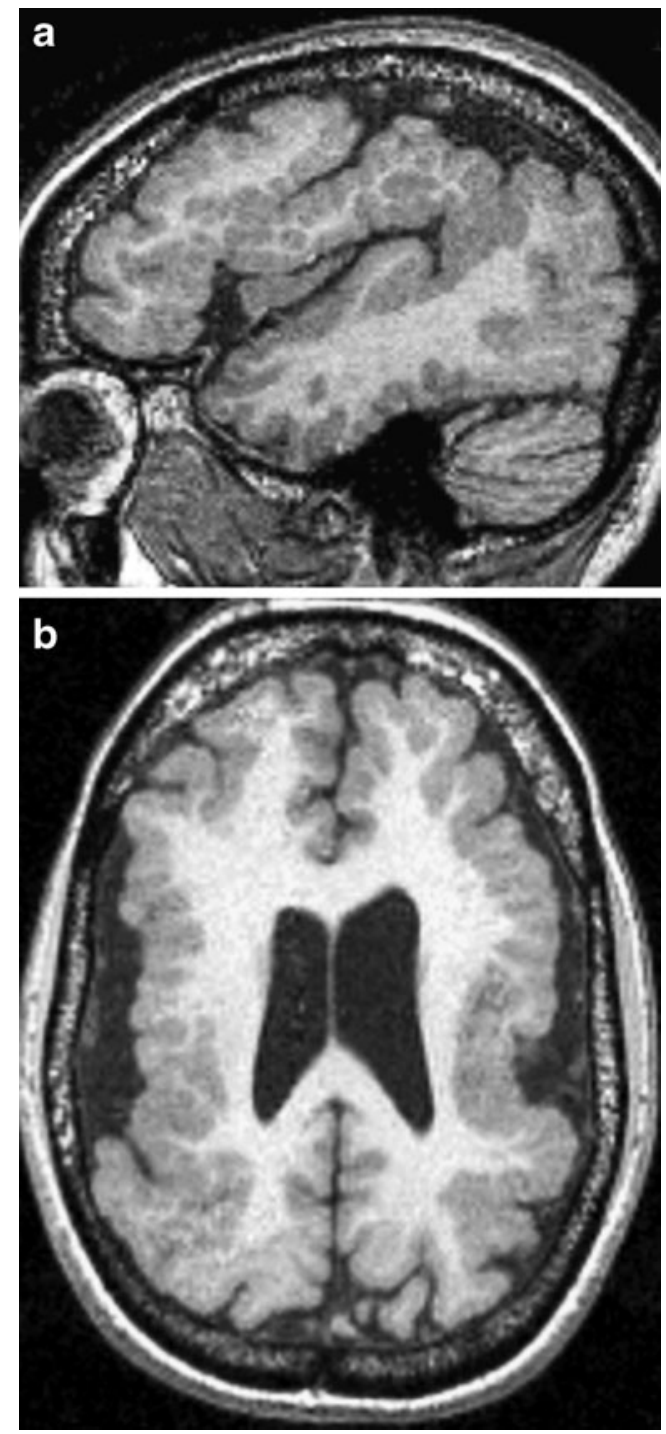

Fig. 6 Grade 1 perisylvian PMG. Parasagittal (a) and axial (b) T1weighted images show coarse polymicrogyria extending from the frontal pole to the occipital pole 
to recognize that anomalous venous drainage is common in areas of dysplastic cortex [43], seen in up to $51 \%$ of patients with polymicrogyria [28]. Large vessels are especially common in regions where there is a large infolding of thickened cortex. Such large vessels, when seen in association with abnormal, thickened cortex, should not be mistaken for vascular malformations. Angiography is not indicated.

Several syndromes of bilateral symmetrical polymicrogyria have been described; these should be recognized by neuroimagers. The best known and most common of these is bilateral perisylvian polymicrogyria (also called congenital bilateral perisylvian syndrome [44]). This syndrome may be sporadic or familial $[15,45]$. The heterogeneous inheritance patterns suggest that mutations of several different genes can cause this malformation [45]; three locations (Xq21.33-q23 (SRPX2), 22q11.2, and Xq28) have been identified $[13,19,20,22]$. Sporadic cases tend to
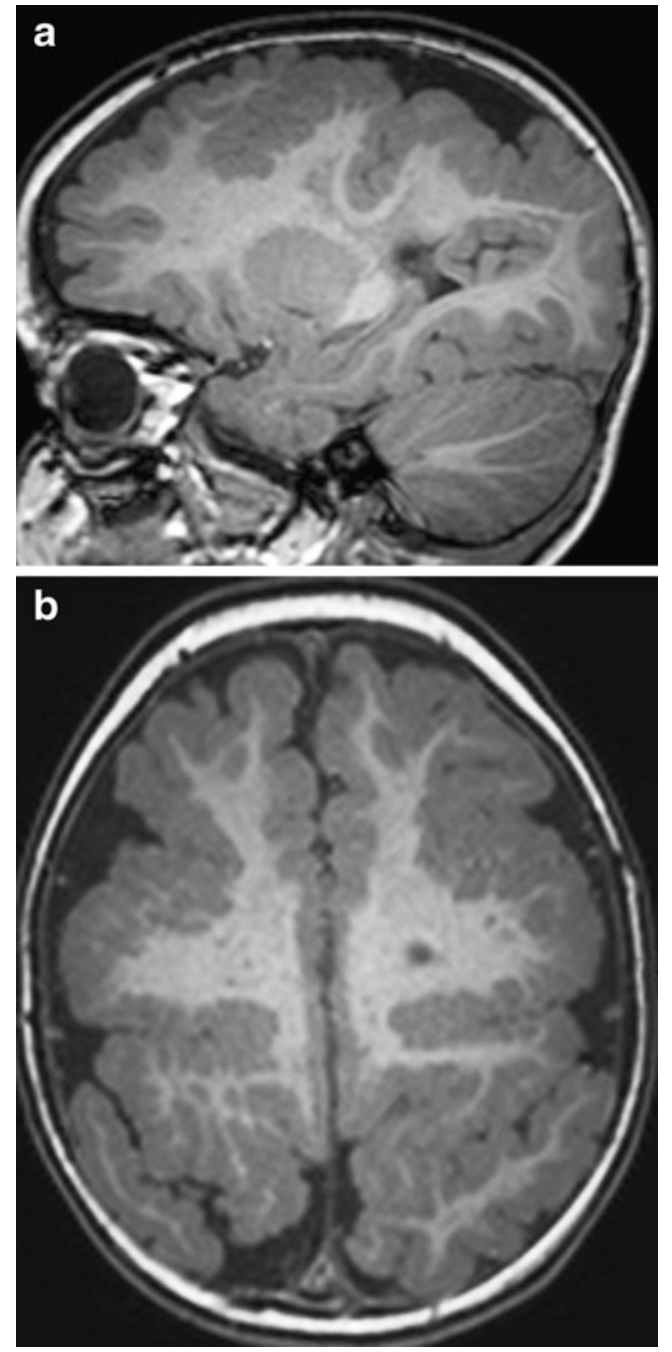

Fig. 7 Grade 2 perisylvian PMG. Parasagittal (a) and axial (b) images show coarse perisylvian polymicrogyria sparing the anterior frontal lobes and the occipital lobes present with more severe neurologic manifestations. A syndrome of developmental pseudobulbar palsy (oropharyngeal dysfunction and dysarthria, 100\%), epilepsy (80$90 \%$ ), mental retardation (50-80\%), and, sometimes, congenital arthrogryposis has been described [44, 46-48]. Other patients are brought to attention in infancy or early childhood because of delayed development (60\%), palatal dysfunction (40\%), hypotonia (30\%), arthrogryposis (30\%), or motor deficits $(25 \%)[47,49]$. Seizures are present in $40-60 \%$ and may be of many clinical types [47, 49]. Studies of familial cases of congenital bilateral perisylvian polymicrogyria show a lower incidence of these clinical manifestations $[45,50]$, possibly because patients with minimal symptoms are more readily identified and examined. A developmental reading disorder and reading impairment without severe motor or cognitive handicap may be the cause of seeking medical attention in this group [51]. Bilateral perisylvian polymicrogyria can be graded
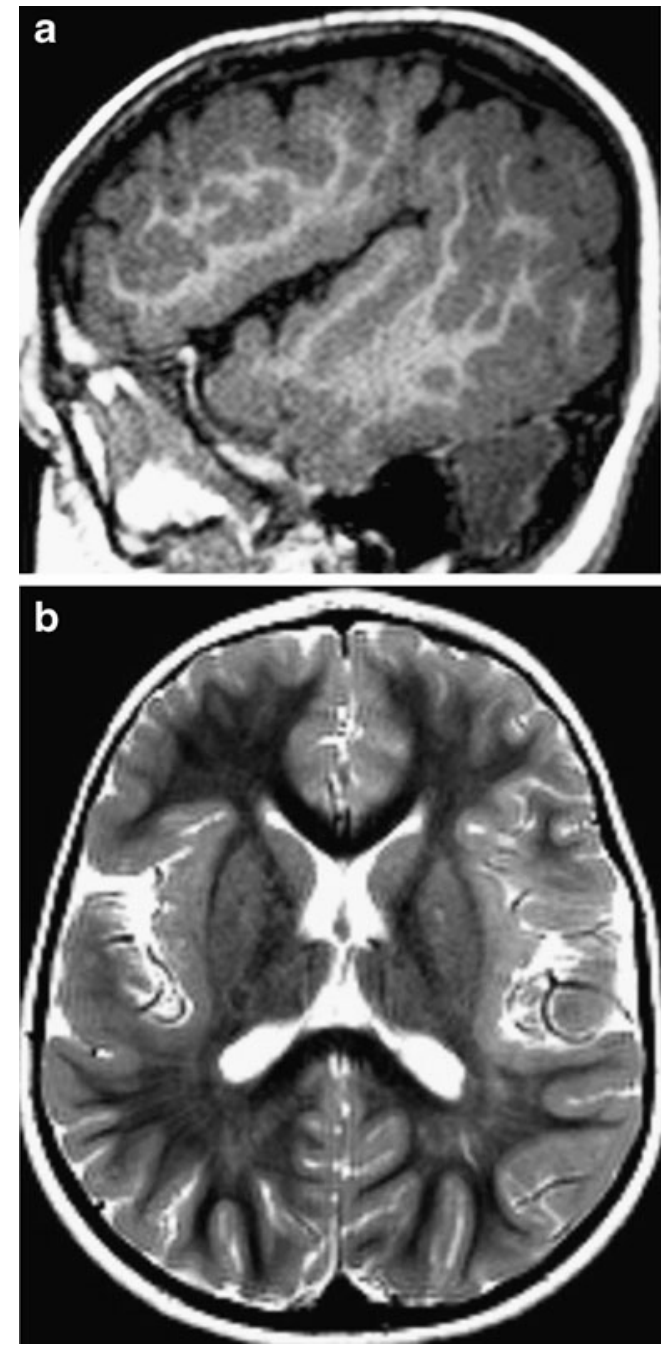

Fig. 8 Grade 3 perisylvian PMG. Parasagittal T1-weighted images (a) and axial T2-weighted images (b) show polymicrogyria limited to the insulae and operculae 
according to severity on MRI (with grade 1 the most severe and grade 4 the mildest) [50]: Grade 1, with perisylvian polymicrogyria extending to the frontal or occipital pole (Fig. 6); Grade 2, with polymicrogyria extending beyond the perisylvian region but not to either pole (most common, Fig. 7); Grade 3, with polymicrogyria of the perisylvian region only (Fig. 8); and Grade 4, with polymicrogyria restricted to the posterior perisylvian regions.

Bilateral frontoparietal polymicrogyria is another welldefined syndrome [12, 52]. Affected patients are characterized by global developmental delay of at least moderate severity, seizures, disconjugate gaze, and bilateral pyramidal and cerebellar signs [52]. MR demonstrates symmetric
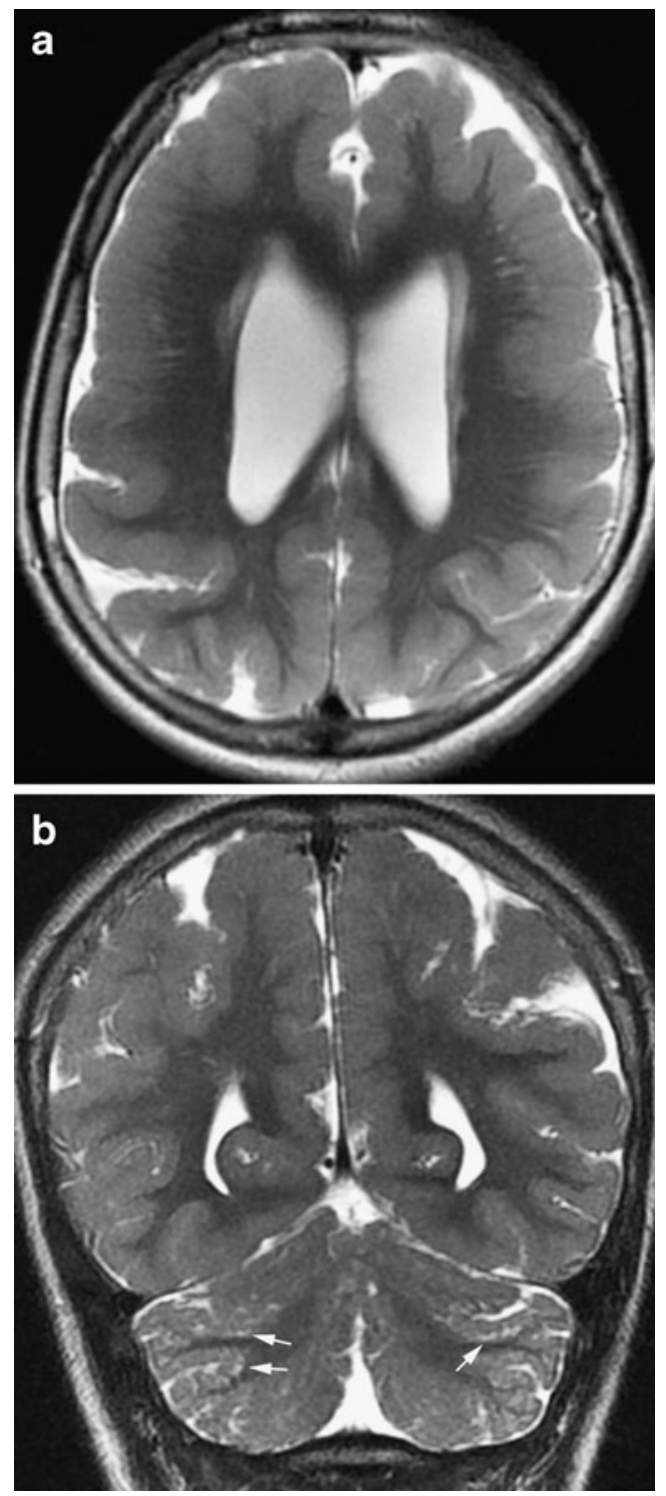

Fig. 9 Bilateral frontoparietal polymicrogyria. Axial (a) and coronal (b) T2-weighted images show a different appearance to the cortex, that of multiple radially oriented neuronal components separated by fibroglial stroma. Note the prominent cerebellar fissures and the subcortical cerebellar cysts (arrows)

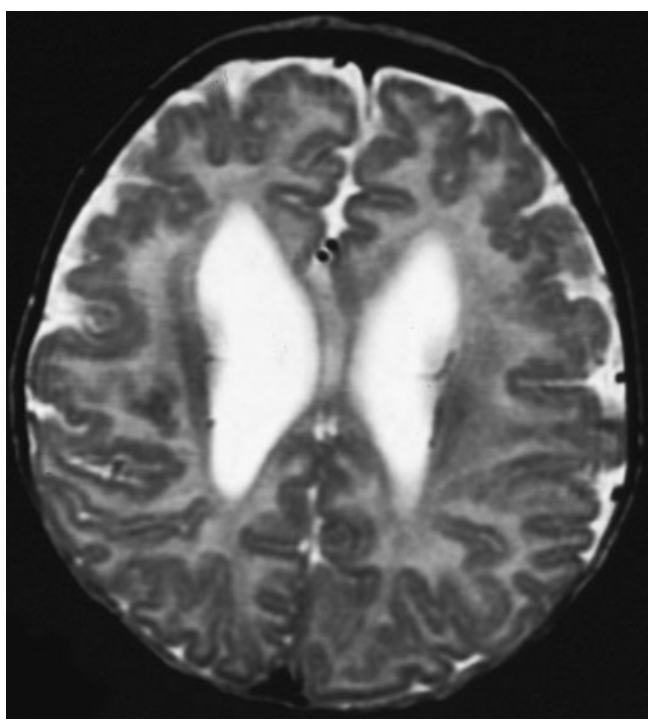

Fig. 10 Bilateral frontal polymicrogyria. Axial T2-weighted image shows delicate PMG in both frontal lobes. The lateral ventricles are somewhat dilated
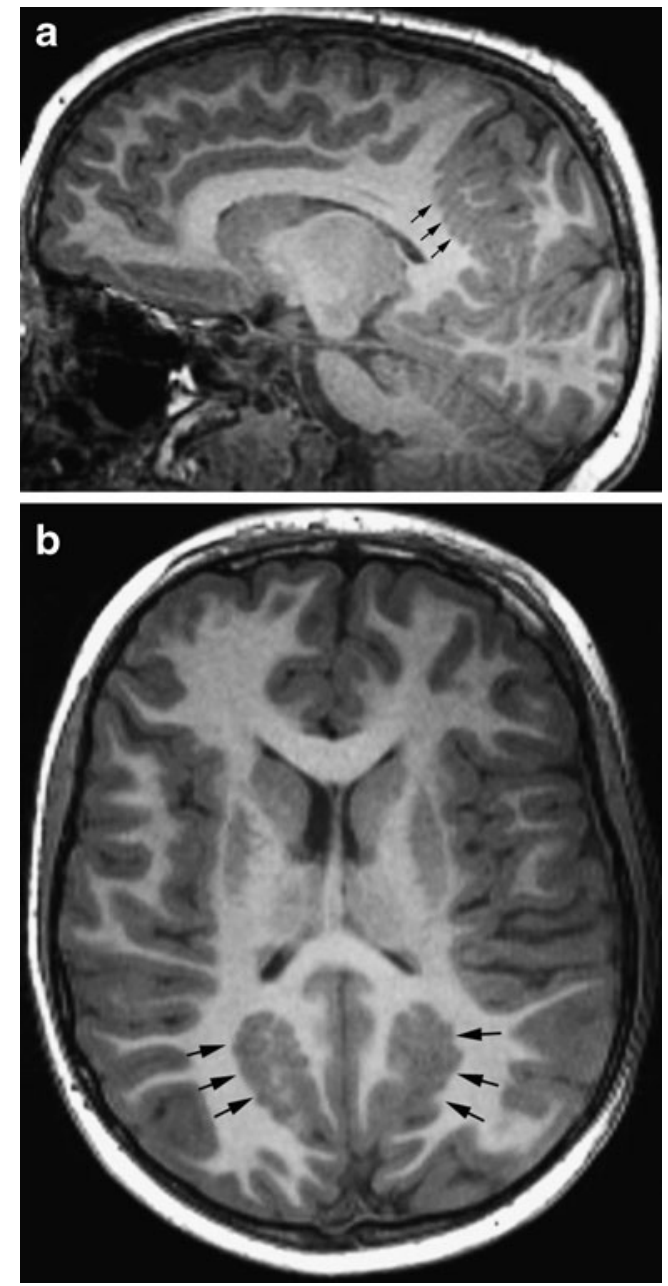

Fig. 11 Bilateral parasagittal parieto-occipital polymicrogyria. Parasagittal (a) and axial (b) T1-weighted images show coarse parasagittal infoldings (arrows) of polymicrogyria 
cortical dysgenesis affecting the frontoparietal regions most severely, as well as ventriculomegaly, bilateral white matter signal changes, and small brainstem and cerebellar structures with dysmorphic cerebellar cortex (Fig. 9). The presence of the white matter changes and the posterior fossa anomalies is very uncommon for polymicrogyria syndromes. In addition, the cortical malformation itself has a slightly different appearance than that of most polymicrogyria. Indeed, the overall appearance of the brain is more similar to that of the so-called cobblestone malformations, associated with congenital muscular dystrophies and resulting from abnormalities of linkage of radial glial cells to the pial basement membrane overlying the developing cortex [53, 54]. Further research has shown that the pial basement membrane is regulated by GPR56, the gene that causes BFPP when mutated [55], and that mutations of GPR56 cause gaps in the pial basement membrane and abnormal linkage of radial glial cells to that membrane [55]. Therefore, this disorder may fit better into the cobblestone malformations. Moreover, this observation raises the question of what precisely defines polymicrogyria and whether the different types of polymicrogyria should be analyzed and distinguished.

Other syndromes of bilateral symmetrical polymicrogyria have been described [56]. Several groups have described patients with spastic quadriparesis and epilepsy, on whom imaging shows bilateral symmetrical frontal polymicrogyria (Fig. 10) [57]. Guerrini et al. have described patients with bilateral medial parietal-occipital polymicrogyria (Fig. 11) $[27,58]$. Other patients have combinations of the abovementioned patterns (Fig. 2); thus, it appears that any region of cortex may be involved by bilateral, symmetrical polymicrogyria [56]. A syndrome of congenital hemiplegia and epilepsy has been described in patients with large areas of unilateral polymicrogyria [59]. These patients typically present in infancy with delayed motor development. A familial syndrome of unilateral polymicrogyria has also been described [60].

A syndrome of megalencephaly with polymicrogyria and hydrocephalus has been described. Affected children present at birth or in early infancy with macrocephaly and hypotonia; delayed motor and cognitive development become evident as they grow. Epilepsy, postaxial polydactyly, cutis marmorata, midface capillary malformation, and coarse facial features are frequently present [61-65]. Imaging reveals ventriculomegaly (from hydrocephalus) and polymicrogyria, which is most severe in the perisylvian region (typically Grade 1 or 2). This disorder is now thought to include those previously called megalencephalypolymicrogyria-polydactyly-hydrocephalus syndrome and macrocephaly capillary malformation syndromes [63-65].

In summary, polymicrogyria is not a single entity, but a group of disorders that has many causes and many clinical and radiological phenotypes. Imaging characteristics may be useful in helping to differentiate the different types of polymicrogyria, which may appear as one component of multiple congenital anomaly syndromes or as isolated CNS malformation. It is important for neuroimagers to acquire high-quality images in affected patients and carefully analyze the images to help to optimize the diagnosis and treatment.

Acknowledgments A.J. Barkovich is funded by NIH R01 NS058721, R01 NS46432, and R37 NS35129.

Conflict of interest statement I declare that I have no conflict of interest.

Open Access This article is distributed under the terms of the Creative Commons Attribution Noncommercial License which permits any noncommercial use, distribution, and reproduction in any medium, provided the original author(s) and source are credited.

\section{References}

1. Barkovich AJ, Kuzniecky RI, Jackson GD, Guerrini R, Dobyns WB (2005) A developmental and genetic classification for malformations of cortical development. Neurology 65:1873-1887

2. Norman MG, McGillivray BC, Kalousek DK, Hill A, Poskitt KJ (1995) Congenital malformations of the brain: pathologic, embryologic, clinical, radiologic and genetic aspects. Oxford University Press, Oxford

3. Barkovich AJ, Gressens P, Evrard P (1992) Formation, maturation, and disorders of brain neocortex. AJNR Am J Neuroradiol 13:423446

4. Evrard P, de Saint-Georges P, Kadhim HJ, Gadisseux J-F (1989) Pathology of prenatal encephalopathies. In: French J (ed) Child neurology and developmental disabilities. Paul H. Brookes, Baltimore, pp 153-176

5. Englund C, Fink A, Lau C et al (2005) Pax6, Tbr2, and Tbr1 are expressed sequentially by radial glia, intermediate progenitor cells, and postmitotic neurons in developing neocortex. J Neurosci $25: 247-251$

6. Barkovich AJ, Linden CL (1994) Congenital cytomegalovirus infection of the brain: imaging analysis and embryologic considerations. AJNR Am J Neuroradiol 15:703-715

7. Wright R, Johnson D, Neumann M et al (1997) Congenital lymphocytic choriomeningitis virus syndrome: a disease that mimics congenital toxoplasmosis or Cytomegalovirus infection. Pediatrics 100:E9

8. Hallervorden J (1949) Ueber eine Kohlenoxydvergiftung im Fetalleben mit Entwicklunsstorung der Hirnrinde. Allg Z Psychiatr 124:289-298

9. Barkovich AJ, Rowley HA, Bollen A (1995) Correlation of prenatal events with the development of polymicrogyria. AJNR Am J Neuroradiol 16:822-827

10. Bingham PM, Lynch D, McDonald-McGinn D, Zackai E (1998) Polymicrogyria in chromosome 22 deletion syndrome. Neurology 51:1500-1502

11. Kuzniecky R (1994) Familial diffuse cortical dysplasia. Arch Neurol 51:307-310

12. Piao X, Basel-Vanagaite L, Straussberg R et al (2002) An autosomal recessive form of bilateral frontoparietal polymicrogyria maps to chromosome 16q12.2-21. Am J Hum Genet 70:1028-1033

13. Villard L, Nguyen K, Cardoso C et al (2002) A locus for bilateral perisylvian polymicrogyria maps to Xq28. Am J Hum Genet 70:1003-1008 
14. Caraballo RH, Cersósimo RO, Mazza E, Fejerman N (2000) Focal polymicrogyria in mother and son. Brain Develop 22:336-339

15. Borgatti R, Triulzi F, Zucca C et al (1999) Bilateral perisylvian polymicrogyria in three generations. Neurology 52:1910-1913

16. Leventer RJ, Lese CM, Cardosi C, Rosenberry J, Weiss A, Stoodley N (2001) A study of 220 patients with polymicrogyria deliniates distinct phenotypes and reveals genetic loci on chromosome $1 \mathrm{p}, 2 \mathrm{p}$, 6q, 21q, 22q, and Xq. Am J Hum Genet 69:177

17. Brooks AS, Bertoli-Avella AM, Burzynski GM et al (2005) Homozygous nonsense mutations in KIAA1279 are associated with malformations of the central and enteric nervous systems. Am J Hum Genet 77:120-126

18. Aligianis IA, Johnson CA, Gissen P et al (2005) Mutations of the catalytic subunit of RAB3GAP cause Warburg Micro syndrome. Nat Genet 37:221-223

19. Robin N, Taylor C, McDonald-McGinn D et al (2006) Polymicrogyria and deletion22q11.2 syndrome: window to the etiology of a common cortical malformation. Am J Med Genet A 140:2416-2425

20. Roll P, Rudolf G, Pereira S et al (2006) SRPX2 mutations in disorders of language cortex and cognition. Hum Mol Genet 15:1195-1207

21. Baala L, Briault S, Etchevers HC et al (2007) Homozygous silencing of T-box transcription factor EOMES leads to microcephaly with polymicrogyria and corpus callosum agenesis. Nat Genet 39:454-456

22. Dobyns WB, Mirzaa G, Christian SL et al (2008) Consistent chromosome abnormalities identify novel polymicrogyria loci in 1p36.3, 2p16.1-p23.1, 4q21.21-q22.1, 6q26-q27, and 21q2. Am J Med Genet Part A 146A:1637-1654

23. Jaglin XH, Poirier K, Saillour Y et al (2009) Mutations in the beta-tubulin gene $T U B B 2 B$ result in asymmetrical polymicrogyria. Nat Genet 41:746-752

24. Guerrini R, Dravet C, Raybaud C et al (1992) Epilepsy and focal gyral anomalies detected by MRI: electroclinico-morphological correlations and follow-up. Dev Med Child Neurol 34:706-718

25. Barkovich AJ, Kjos BO (1992) Non-lissencephalic cortical dysplasia: correlation of imaging findings with clinical deficits. AJNR Am J Neuroradiol 13:95-103

26. Leventer R (2007) Polymicrogyria and related disorders of cortical development: a clinical, imaging, and genetic study. In: Child Health Institute. Melbourne, Australia: University of Melbourne 411

27. Guerrini R, Dubeau F, Dulac O et al (1997) Bilateral parasagittal parietooccipital polymicrogyria and epilepsy. Ann Neurol 41:65-73

28. Hayashi N, Tsutsumi Y, Barkovich AJ (2002) Morphological features and associated anomalies of schizencephaly in the clinical population: detailed analysis of MR images. Neuroradiology 44:418-427

29. Barkovich AJ, Millen KJ, Dobyns WB (2007) A developmental classification of malformations of the brainstem. Ann Neurol 62:625-639

30. Wieck G, Leventer RJ, Squier WM et al (2005) Periventricular nodular heterotopia with overlying polymicrogyria. Brain 128:2811-2821

31. Barkovich AJ (2000) Morphology of subcortical heterotopia: a magnetic resonance study. AJNR Am J Neuroradiol 21:290-295

32. Aicardi J (2005) Aicardi syndrome. Brain Develop 27:164-171

33. Aicardi J, Lefebre J, Lerrique-Koechlin A (1965) A new syndrome: spasm in flexion, callosal agenesis, ocular abnormalities. Electroencephalogr Clin Neurophysiol 19:609-610

34. Moog U, Jones MC, Bird LM, Dobyns WB (2005) Oculocerebrocutaneous syndrome: the brain malformation defines a core phenotype. J Med Genet 42:913-921

35. Pascual-Castroviejo I, Pascual-Pascual SI, Velazquez-Fragua R, Lapunzina P (2005) Oculocerebrocutaneous [Delleman] syndrome: report of two cases. Neuropediatrics 36:50-54
36. Warburg M, Sjo O, Fledelius H, Pederson S (1993) Autosomal recessive microcephaly, microcornea, congenital cataract, mental retardation, optic atrophy, and hypogenitalism. Micro syndrome. Am J Dis Child 12:1309-1312

37. Nassogne M, Henrot B, Saint-Martin C, Kadhim H, Dobyns W, Sebire G (2000) Polymicrogyria and motor neuropathy in Micro syndrome. Neuropediatrics 31:218-221

38. Graham JM Jr, Hennekam R, Dobyns WB, Roeder E, Busch D (2004) MICRO syndrome: an entity distinct from COFS syndrome. Am J Med Genet A 128:235-245

39. Ferdinandusse S, Denis S, Mooyer PAW et al (2006) Clinical and biochemical spectrum of D-bifunctional protein deficiency. Ann Neurol 59:92-104

40. Barkovich AJ (2009) MRI analysis of sulcation morphology in polymicrogyria. Epilepsia

41. Raybaud C, Girard N, Canto-Moreira N, Poncet M (1996) Highdefinition magnetic resonance imaging identification of cortical dysplasias: micropolygyria versus lissencephaly. In: Guerrini R, Andermann F, Canapicchi R, Roger J, Zifkin B, Pfanner P (eds) Dysplasias of cerebral cortex and epilepsy. Lippincott-Raven, Philadelphia, pp 131-143

42. Takanashi J, Barkovich A (2003) The changing MR imaging appearance of polymicrogyria: a consequence of myelination. AJNR Am J Neuroradiol 24:788-793

43. Barkovich AJ (1988) Abnormal vascular drainage in anomalies of neuronal migration. AJNR Am J Neuroradiol 9:939-942

44. Kuzniecky R, Andermann F, Guerrini R (1993) Congenital bilateral perisylvian syndrome: study of 31 patients. The congenital bilateral perisylvian syndrome milticenter collaborative study. Lancet 341:608-612

45. Guerreiro MM, Andermann E, Guerrini R et al (2000) Familial perisylvian polymicrogyria: a new familial syndrome of cortical maldevelopment. Ann Neurol 48:39-48

46. Guerrini R, Dravet C, Raybaud C et al (1992) Neurological findings and seizure outcome in children with bilateral opercular macrogyric-like changes detected by MRI. Dev Med Child Neurol 34:694-705

47. Gropman AL, Barkovich AJ, Vezina LG, Conry JA, Dubovsky EC, Packer RJ (1997) Pediatric congenital bilateral perisylvian syndrome: clinical and MRI features in 12 patients. Neuropediatrics 28:198-203

48. Becker PS, Dixon AM, Troncoso JC (1989) Bilateral opercular polymicrogyria. Ann Neurol 25:90-92

49. Rolland Y, Adamsbaum C, Sellier N, Robain O, Ponsot G, Kalifa G (1995) Opercular malformations: clinical and MRI features in 11 children. Pediatr Radiol 25:S2-S8

50. Jansen A, Andermann E (2005) Genetics of the polymicrogyria syndromes. J Med Genet 42:369-378

51. Oliveira EPM, Hage SRV, Guimaraes C et al (2008) Characterization of language and reading skills in familial polymicrogyria. Brain Dev 30:254-260

52. Chang B, Piao X, Bodell A et al (2003) Bilateral frontoparietal polymicrogyria: clinical and radiological features in 10 families with linkage to chromosome 16. Ann Neurol 53:596-606

53. Moore SA, Saito F, Chen J et al (2002) Deletion of brain dystroglycan recapitulates aspects of congenital muscular dystrophy. Nature 418:422-425

54. Michele DE, Barresi R, Kangawa $M$ et al (2002) Post-translational disruption of dystroglycan-ligand interactions in congenital muscular dystrophies. Nature 418:417-422

55. Li S, Jin Z, Koirala S et al (2008) GPR56 regulates pial basement membrane integrity and cortical lamination. J Neurosci 28:58175826

56. Barkovich AJ, Hevner R, Guerrini R (1999) Syndromes of bilateral symmetrical polymicrogyria. AJNR Am J Neuroradiol 20:1814-1821 
57. Guerrini R, Barkovich A, Sztriha L, Dobyns W (2000) Bilateral frontal polymicrogyria. Neurology 54:909-913

58. Guerrini R, Dulac O, Canapicchi R et al (1994) Epilepsie révélatrice d'une dysplasie corticale occipito-pariétale parasagittale bilatérale. Epilepsies 6:131-139

59. Pascual-Castroviejo I, Pascual-Pascual S, Viano J, Martinez V, Palencia R (2001) Unilateral polymicrogyria: a common cause of hemiplegia of prenatal origin. Brain Dev 23:216-222

60. Chang BS, Apse KA, Caraballo R et al (2006) A famillial syndrome of unilateral polymicrogyria affecting the right hemisphere. Neurology 66:133-135

61. Moore C, Toriello H, Abuelo D et al (1997) Macrocephaly-cutis marmorata telangiectatica congenita: a distinct disorder with developmental delay and connective tissue abnormalities. Am J Med Genet 70:67-73
62. Giuliano F, David A, Edery P et al (2004) Macrocephaly-cutis marmorata telangiectatica congenita: seven cases including two with unusual cerebral manifestations. Am J Med Genet A 126A:99-103

63. Mirzaa G, Dodge NN, Glass I et al (2004) Megalencephaly and perisylvian polymicrogyria with postaxial polydactyly and hydrocephalus: a rare brain malformation syndrome associated with mental retardation and seizures. Neuropediatrics 35:353-359

64. Garavelli L, Guareschi E, Errico S et al (2007) Megalencephaly and Perisylvian Polymicrogyria with Postaxial Polydactyly and Hydrocephalus [MPPH]: report of a new case. Neuropediatrics 38:200-203

65. Gripp KW, Hopkins E, Vinkler C et al (2009) Significant overlap and possible identity of macrocephaly capillary malformation and megalencephaly polymicrogyria-polydactyly hydrocephalus syndromes. Am J Med Genet A 149A:868-876 